\title{
Behavior of Strengthened Composite Prestressed Concrete Girders under Static and Repeated Loading
}

\author{
Abbas AbdulMajeed Allawi \\ Department of Civil Engineering, University of Baghdad, 17001 Baghdad, Iraq \\ Correspondence should be addressed to Abbas AbdulMajeed Allawi; a.allawi@uobaghdad.edu.iq
}

Received 23 June 2017; Revised 5 October 2017; Accepted 1 November 2017; Published 27 December 2017

Academic Editor: Ghassan Chehab

Copyright (c) 2017 Abbas AbdulMajeed Allawi. This is an open access article distributed under the Creative Commons Attribution License, which permits unrestricted use, distribution, and reproduction in any medium, provided the original work is properly cited.

\begin{abstract}
The use of external posttensioning technique for strengthening reinforced concrete girders has been considerably studied by many researchers worldwide. However, no available data are seen regarding strengthening full-scale composite prestressed concrete girders with external posttensioned technique under static and repeated loading. In this research, four full-scale composite prestressed I-shape girders of $16 \mathrm{~m}$ span were fabricated and tested under static and repeated loading up to failure. Accordingly, two girders were externally strengthened with posttensioned strands, while the other two girders were left without strengthening. The experimental tests include deflection, cracking load, ultimate strength and strains at midspan, and loading stages. Test results were compared with the design expressions mentioned in AASHTO LRFD specifications and ACI 318-2014 code. Also, a nonlinear analysis was conducted using the finite element method (FEM). The presented analysis models were verified by comparing the model results with test results. The general theme abstracted from both experimental tests and numerical analysis reflects that the performance and procedure of strengthening with external prestressing of girders were found to be effective in increasing the load carrying capacity of the strengthened girders.
\end{abstract}

\section{Introduction}

Repairing and strengthening of deteriorated, damaged, and substandard infrastructure has become one of the important challenges facing structural engineers worldwide. There are significant and growing needs for strengthening existing reinforced concrete structures. Although the use of unbonded tendons as the major prestressing technique in design and rehabilitation has been favored for reasons of ease of construction, cost-effectiveness, and maintenance, the overall structural behavior of prestressed with externally unbonded tendon under flexural loading is yet to be well understood, as little work has been done in this field [1].

Bending failure of beams with unbonded tendons was studied by Naaman and Alkhairi [2]. They have proposed a simplified methodology for ultimate strength limit state analysis by extending the concept of elastic cracked strain reduction coefficient to include the limit state. Accordingly, the authors suggested the following expression, depending on the bond reduction factor, for the ultimate tendon stress $f_{\mathrm{ps}}$ :

$$
f_{\mathrm{ps}}=f_{\mathrm{pe}}+\Omega_{u} E_{p} \varepsilon_{\mathrm{cu}}\left(\frac{d_{p}}{c}-1\right) \frac{L_{1}}{L_{2}} \leq 0.94 f_{\mathrm{py}}(\mathrm{MPa})
$$

in which $f_{\mathrm{pe}}$ and $f_{\mathrm{py}}$ are, respectively, the effective and yield stresses in the steel tendons, $\Omega_{u}$ is the bond reduction factor which is equal to $k /\left(L / d_{p}\right), k=1.5$ for one-point loading and 3.0 for third-point and uniform loading, $L$ is the span length, $d_{p}$ is the depth from the extreme compression fiber to the centroid of the prestressing steel, $E_{p}$ is Young's modulus for the steel tendons, $\varepsilon_{\mathrm{cu}}$ is the ultimate compressive strain in concrete and is taken equal to $0.003, c$ is the neutral axis depth, $L_{1}$ is the length of loaded span or sum of loaded spans affected by the same unbonded tendon, and $L_{2}$ is the total length of the unbonded tendons between end anchorages.

In prestressed concrete girders with unbonded tendons (internal or external), the stress increment in tendons depends 
on the geometrical and material deformations of the member. So it cannot be determined from individual section analysis. AASHTO LRFD [3] (provisions (5.7.3.1.2)) states the following expression for the stress in unbonded tendons $f_{\mathrm{ps}}$, which is based on Pannell's deformation-based model:

$$
f_{\mathrm{ps}}=f_{\mathrm{pe}}+\frac{6300\left(d_{p}-c\right)}{l_{e}}(\mathrm{MPa}),
$$

where $l_{e}=L /(1+N / 2)$, in which $L$ is the length of tendon between anchorages or fully bonded deviators and $N$ is the number of support hinges required to form a failure mechanism crossed by the tendon, $d_{p}$ is distance from the extreme compression fiber to the centroid of the prestressing steel, and $c$ is the neutral axis depth.

The ACI 318-2014 code [4] provision (20.3.2.4.1) introduces the following relation to calculate $f_{\mathrm{ps}}$ :

$$
f_{\mathrm{ps}}=f_{\mathrm{pe}}+70+\frac{f_{c}^{\prime}}{\lambda \rho_{p}}(\mathrm{MPa}),
$$

where $\rho_{p}=A_{p} / \mathrm{bd}$, for span/depth ratio equal or less than 35 , $\lambda$ is equal to 100 and $f_{\mathrm{ps}}$ shall not be taken greater than the lesser of $f_{\mathrm{py}}$ and $\left(f_{\mathrm{pe}}+420\right)$, and for span/depth ratio more than $35, \lambda$ is taken as 300 and $f_{\mathrm{ps}}$ shall not be taken greater than the lesser of $f_{\mathrm{py}}$ and $\left(f_{\mathrm{pe}}+210\right)$.

It can be pointed out that external prestressing is considered to be one of the useful techniques for strengthening or renovation of structures in service. This system had grown recently to occupy a significant share of the construction market. Also, the external prestressing system is simpler to install and easier to inspect and maintain as compared with the internal tendon system, and it has been proposed in the design and construction of new segmental bridges [5].

An experimental investigation was carried out to study the flexural behavior of continuous concrete beams prestressed using external tendons by Harajli et al. [6]. They examined experimentally the behavior of continuous externally prestressed members and developed an analytical approach to predict their ultimate flexural response, taking into consideration the influence of the second-order effects and rotation capacity in the plastic region and other important parameters that were not taken into account in the ACI 318 Building Code. Tan and Tjandra [7] tested four twospan continuous externally prestressed T-beams. The results showed that the strengthened beam could fail in shear, particularly at the high-shear region near the interior support, due to the limited enhancement in shear capacity.

$\mathrm{Ng}$ and Tan [8] conducted an experimental work to investigate the flexural behavior of nine reinforced concrete beams with T-section strengthened by two external tendons under static two-point loading. Two groups of specimens were tested where the main parameters are the span to depth ratios and number of deviators. It is worth to mention that the stress in external tendons increased as the number of deviators increased, especially beyond the cracking load, where the increase became larger as the loading was progressing to the yield and ultimate stages.

Sivaleepunth et al. [9] conducted an experimental investigation on three prototypes of prestressed concrete beams with external tendons by varying the geometry of loading. All beams are T-section, simply supported with overall length of $3300 \mathrm{~mm}$. Two draped 7-wire prestressing tendons, with a nominal diameter of $15.24 \mathrm{~mm}$, were used for each specimen as external tendons with effective prestress $f_{\text {pe }}$ of about $0.55 f_{\mathrm{pu}}$ and effective depth at midspan of $200 \mathrm{~mm}$. The load geometries, which are considered as the main parameter for this study, are one-point loading at midspan, two-point loading with a length of pure moment zone of $500 \mathrm{~mm}$ and two-point loading with a length of pure moment zone of $1000 \mathrm{~mm}$. Accordingly, a comparison has been done of the test results of the stress in tendon at ultimate stage with the results of equations recommended by ACI 318-99 and AASHTO LRFD (2004) design codes [5].

Lee et al. [10] investigated the shear strengthening of continuous concrete beams using externally prestressed steel bars with a V-shape profile. Three beams of $400 \times 600 \mathrm{~mm}$ rectangular section and $9400 \mathrm{~mm}$ total length each one were tested. One beam was considered as unstrengthened control beam, while the remaining beams were strengthened with 18 or $22 \mathrm{~mm}$ steel bars. The steel bars were prestressed up to $35 \%$ of the nominal yield stress. The shear capacity of these continuous beams was calculated according to the provisions of both ACI 318-11 code and AASHTO LRFD specifications for prestressed girders. They suggested that both code provisions give good prediction for the shear strength of externally prestressed beams.

Elrifai et al. [11] studied the fatigue performance of reinforced concrete beams strengthened with externally posttensioned (CFRP) tendons. In their work, five unstrengthened and thirteen strengthened RC beams with different strengthening schemes were tested under different fatigue load ranges up to failure. The behavior of strengthened beams with CFRP tendons showed good fatigue performance with respect to the unstrengthened beams. The flexural behavior of strengthened continuous unbonded posttensioned concrete beams with end-anchored CFRP laminates was examined by Ghasemi et al. [12] by adopting two different configurations of end-anchorage methods. Five beams of two span unbonded posttensioned of $6000 \mathrm{~mm}$ total length were experimentally tested, in which four beams were strengthened with CFRP laminates with different widths. It was concluded that, for continuous beams, the increase in flexural capacity is more pronounced at the serviceability stage than ultimate stage. Also, Chan and $\mathrm{Au}$ [13] studied the behavior of continuous prestressed concrete beams with external unbonded tendons with respect to moment-curvature curves and moment redistribution. Design equations are suggested to calculate the curvature ductility index of such cases.

El-Zohairy and Salim [14] performed a parametric study for posttensioned composite beams with external tendons. An FEM model is presented to simulate composite beam strengthened with externally posttensioned tendons, and the analysis results are verified with existing test data. Strengthening parameters include drap or straight tendons, tendon length, eccentricity, and shear connection details. Analysis results show that the trapezoidal profile gives good behavior rather than straight profile with the same 


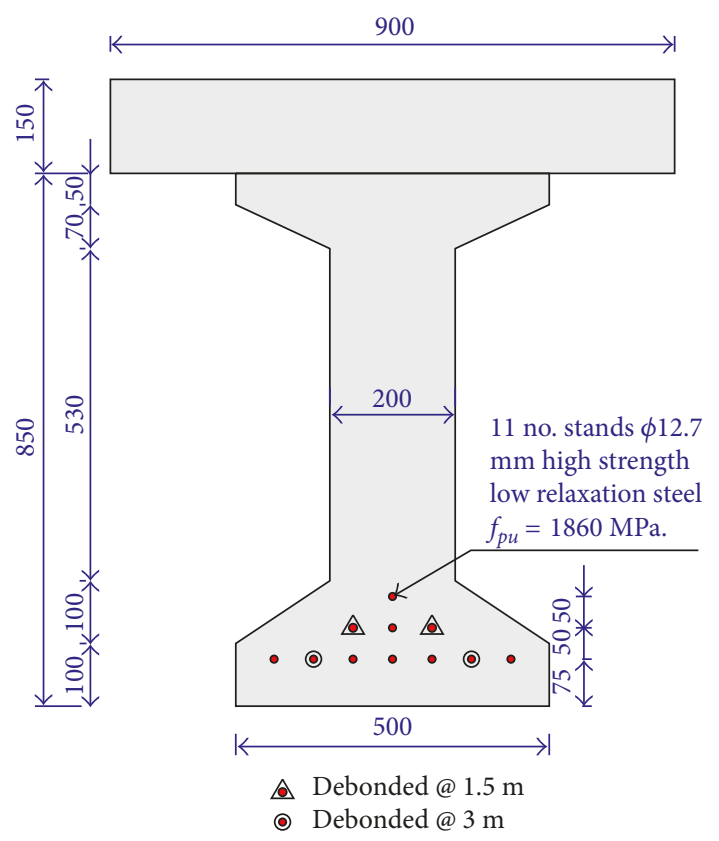

(a)

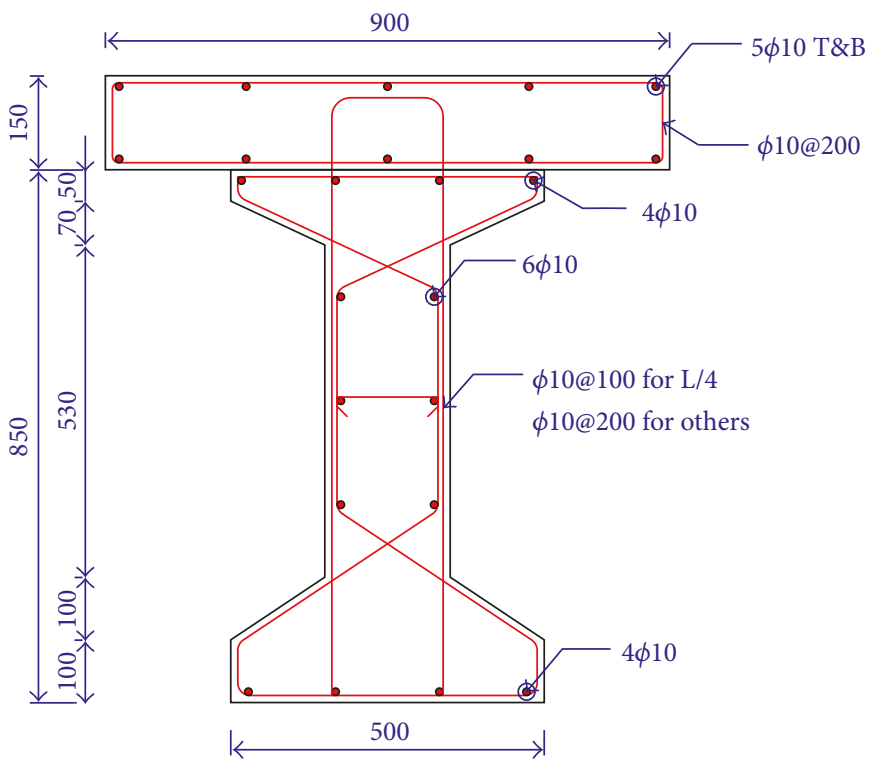

(b)

Figure 1: Dimensions and reinforcement details of the tested girders. (a) Dimensions and prestressing reinforcement details. (b) Nonprestressing reinforcement details.

TABLe 1: Girders details and concrete test results.

\begin{tabular}{|c|c|c|c|c|c|c|c|c|c|}
\hline \multirow[t]{2}{*}{ Group } & \multirow{2}{*}{$\begin{array}{c}\text { Girder } \\
\text { designation }\end{array}$} & \multirow[t]{2}{*}{ Scheme } & \multirow{2}{*}{$\begin{array}{l}\text { Loading } \\
\text { type }\end{array}$} & \multicolumn{3}{|c|}{$\begin{array}{l}\text { Concrete properties } \\
\text { for I-shaped girders }\end{array}$} & \multicolumn{3}{|c|}{$\begin{array}{l}\text { Concrete properties } \\
\text { for deck slab }\end{array}$} \\
\hline & & & & $\left(f_{c}^{\prime}\right) \mathrm{MPa}$ & $\left(f_{\mathrm{ct}}\right) \mathrm{MPa}$ & $\left(E_{c}\right) \mathrm{MPa}$ & $\left(f_{c}^{\prime}\right) \mathrm{MPa}$ & $\left(f_{\mathrm{ct}}\right) \mathrm{MPa}$ & $\left(E_{c}\right) \mathrm{MPa}$ \\
\hline I & G1 & Unstrengthened & Static & \multirow{3}{*}{38.4} & \multirow{3}{*}{4.25} & \multirow{3}{*}{29,725} & \multirow{3}{*}{37.8} & \multirow{3}{*}{4.19} & \multirow{3}{*}{29,438} \\
\hline 1 & G2 & Unstrengthened & Repeated & & & & & & \\
\hline II & $\begin{array}{l}\mathrm{P} 1 \\
\mathrm{P} 2\end{array}$ & $\begin{array}{l}\text { Strengthened } \\
\text { Strengthened }\end{array}$ & $\begin{array}{c}\text { Static } \\
\text { Repeated }\end{array}$ & & & & & & \\
\hline
\end{tabular}

$f_{c}^{\prime}$ : concrete composite strength, $f_{\mathrm{ct}}$ : concrete splitting strength, $E_{c}$ : modulus of elasticity of concrete.

eccentricity for the strengthened composite beams, but with less ductility. Also, it is noted that a better performance of the external posttensioning strengthening scheme can be obtained when the degree of shear connections is greater than $80 \%$. The objective of this paper is to examine experimentally and numerically the benefits of using external prestressing in strengthening of composite prestressed concrete girders to evaluate its effect on both the service load behavior and the load carrying capacity under monotonic static and repeated loadings.

\section{Experimental Program}

2.1. Test Girder Details and Fabrication. In an attempt to evaluate the performance and carrying capacity of composite prestressed concrete girders under static and repeated loading, four full-scale partially prestressed concrete composite girders have been designed, fabricated, and tested to failure, and they are divided into two groups. The first group included unstrengthened girder G1 and strengthened girder P1 which were tested under static load condition, whereas the second group included unstrengthened girder G2 and strengthened girder P2 which were tested under repeated load scheme. These series of girders are used for highway bridges in Iraq for moderate spans of $15,900 \mathrm{~mm}$ in which the I-shaped precast prestressed concrete girder assumed to act as composite beam with the cast in situ concrete deck slab having a width of $900 \mathrm{~mm}$ and a depth of $150 \mathrm{~mm}$. The dimensions of deck slab were selected according to the manufacturer (Hamorabi Company for Contracts/Ministry of Housing and Construction/Iraq) manual for prestressed girders having the same span. These girders have been designed to satisfy IRAQI and AASHTO specifications for prestressed concrete bridges. The cross section, dimensions, and reinforcement of the composite girders are detailed in Figure 1 and Table 1.

Each I-shaped girder was pretensioned by eleven $12.7 \mathrm{~mm}$ nominal diameter of low relaxation strands grade $1860 \mathrm{MPa}$ (Table 2). Four strands were debonded at the end spans to avoid extra tensile stresses at ends at the transfer stage of prestressing (Figure 1), where two of them debonded for $1500 \mathrm{~mm}$ and the other two for $3000 \mathrm{~mm}$ from each end. 
TABle 2: Properties of the strands.

\begin{tabular}{lccccc}
\hline $\begin{array}{l}\text { Nominal } \\
\text { diameter, } \mathrm{mm}\end{array}$ & Grade, $\mathrm{MPa}$ & $\begin{array}{c}\text { Nominal } \\
\text { area, } \mathrm{mm}^{2}\end{array}$ & $\begin{array}{c}\text { Breaking } \\
\text { strength, } \mathrm{kN}\end{array}$ & $\begin{array}{c}\text { Modulus of } \\
\text { elasticity, } \mathrm{MPa}\end{array}$ & $\mathcal{E}_{y}$ \\
\hline 12.7 & 1860 & 98.7 & 183.7 & 190,000 & 0.01 \\
15.24 & 1860 & 140 & 260.7 & 190,000 & 0.03 \\
\hline
\end{tabular}
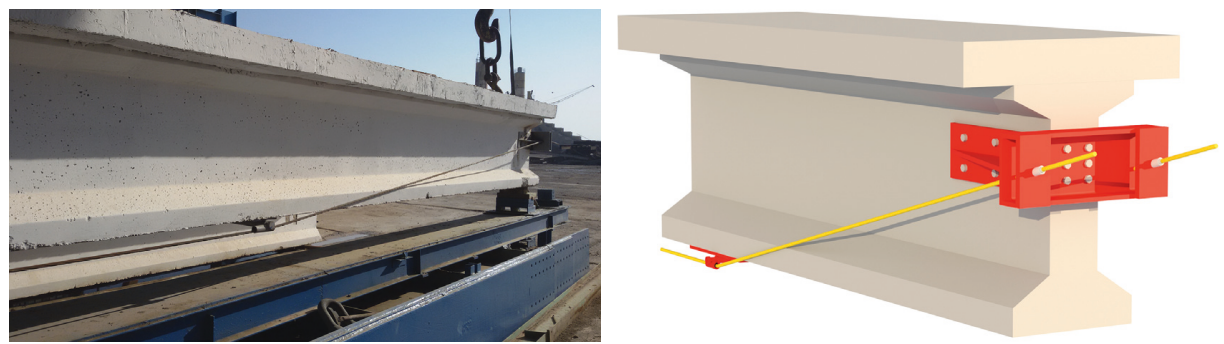

FiguRE 2: External prestressing scheme for strengthening.

Also, the concrete girders were reinforced with four longitudinal nonprestressed steel bars $10 \mathrm{~mm}$ nominal diameter in compression and tension zones where the yield strength is $540 \mathrm{MPa}$. To avoid shear failure, transverse steel bars of $10 \mathrm{~mm}$ diameter were used that spaced at $100 \mathrm{~mm} \mathrm{c} / \mathrm{c}$ at the end quarters and $200 \mathrm{~mm}$ at the middle of the span. Accordingly, these bars extended above the extreme top concrete fibers of the I-shaped girder for $100 \mathrm{~mm}$ to achieve the role of shear connector with the concrete deck. It is worth to mention that all girders were fabricated and cast at the same time after the prestressing strands were pretensioned to the design prestress level. The prestressing force was released 10 hours after concrete casting using flame cutting, where the concrete compressive strength attained about $80 \%$ of the expected strength at 28 days by using the accelerated steam curing method.

The deck slabs were cast 14 days after casting the I-shaped girders. During this period, camber progress was monitored on daily basis under the effect of the prestressing force and the self-weight moment. The recorded average value at midspan, for all I-shaped girders just before casting of the deck slab, was $27 \mathrm{~mm}$. The I-shaped girders were unshored during the casting process of the deck slabs. So, loading affecting them are the prestressing force, the selfweight of the girder, and the weight of the deck slab. It was observed that, at the completion of casting the deck slab, the residual camber value was $22 \mathrm{~mm}$. It should be mentioned that composite girders G1 and P1 were tested under static monotonic loading, while girders G2 and P2 were tested under nonreverse repeated loading. External posttensioning strengthening technique was selected to resolve the deficiency due to moment carrying capacity. Composite girders G2 and P2 were externally posttensioning using two $15.24 \mathrm{~mm}$ nominal diameter low relaxation strands grade $1860 \mathrm{MPa}$ (Table 2) [15], which were located at symmetrical distances of $25 \mathrm{~mm}$ from either side relative to the longitudinal axis of the girder (Figure 1) in which the additional induced stresses at extreme fibers of composite concrete section were checked with the permissible stresses stated in both ACI 318-2014 code and AASHTO LRFD specifications at the initial stage. A jaw-and-barrel system was used to grip the steel strands. The two strands were tensioned simultaneously from one end using the same ram used in tensioning the internal prestressing strands. Special care was exercised to balance the prestressing force in strands to avoid biaxial bending of the specimens. According to AASHTO limitations, the target effective prestress force in external prestressing strands was $60 \%$ of the breaking strength.

The corresponding stress was monitored accurately using the readings of the pressure gauge of the hydraulic ram used in the prestressing operation. During the external prestressing, the composite girders deflected upward where the accumulative camber value was $38 \mathrm{~mm}$. The wedgeanchored prestressing strands were supported directly on a specially designed U-shaped steel anchor assemblies which attached to both ends of the girder using eighteen $20 \mathrm{~mm}$ diameter high-strength steel bolts. The U-shaped steel anchor assembly consists of steel channel sections of C240 $\mathrm{mm}$ depth and $600 \mathrm{~mm}$ length covered, at ends, by two welded steel bearing plates of $150 \mathrm{~mm}$ wide $\times 240 \mathrm{~mm}$ depth $\times 24 \mathrm{~mm}$ thick used for the deviated strands to comply with their inclined profile, in addition to two steel brackets which are welded back to back to the steel channel (Figures 2 and 3(a)).

These brackets were fixed to both sides of the girder web, and each of them included one steel plate of $16 \mathrm{~mm}$ thick welded with one-tapered steel stiffeners of the same thickness. The U-shaped anchor assembly D1 was located at the center of the composite concrete end section to eliminate the eccentricity of the prestressing strands at these sections (Figures 3(b) and 3(c)). To perform the draped profile for the strands, two steel deviators D2 were used at $5300 \mathrm{~mm}$ from each end section. Each deviator consisted of $50 \mathrm{~mm}$ diameter cylindrical shaft with $20 \mathrm{~mm}$ groove welded to $200 \mathrm{~mm}$ wide $\times 12 \mathrm{~mm}$ thick $\times 500 \mathrm{~mm}$ long rectangular steel plate attached at the soffit of the girder at those sections using six $10 \mathrm{~mm}$ steel bolts as shown in Figure 3(d). The external strands were located $75 \mathrm{~mm}$ below the soffit of the girders. At the completion of the external prestressing process, the accumulative camber value was $31 \mathrm{~mm}$. 


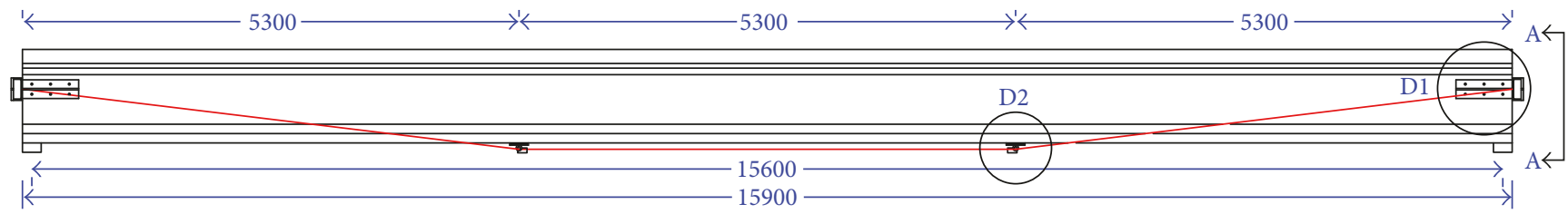

(a)

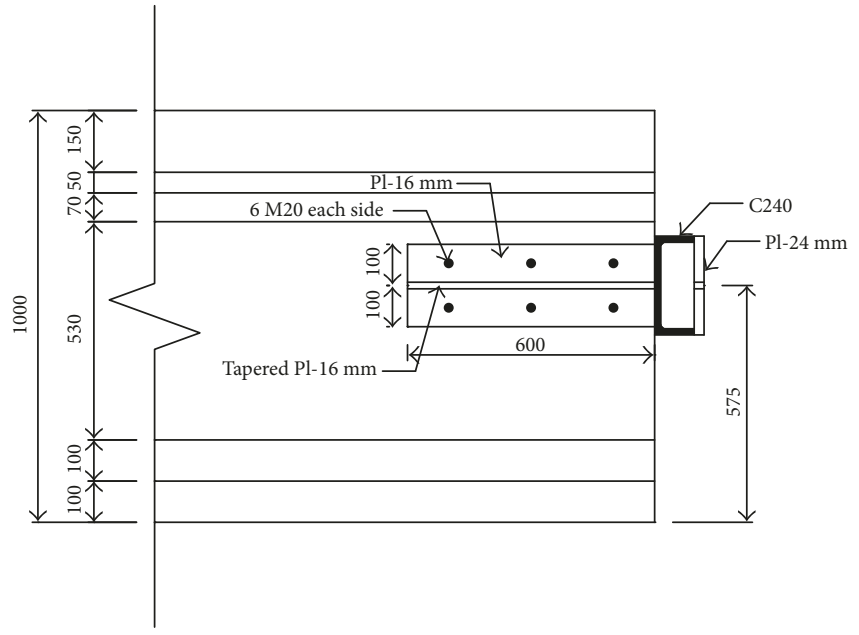

(b)

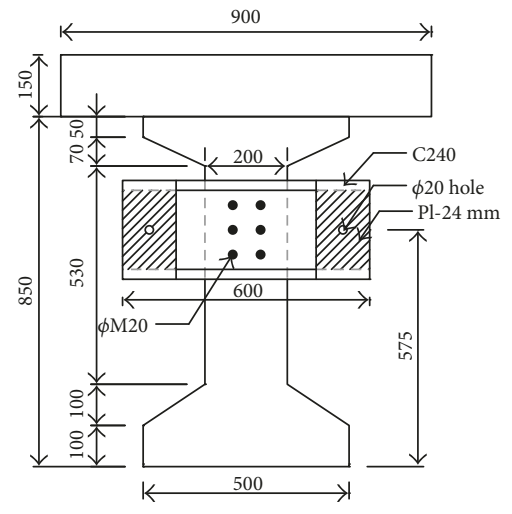

(c)

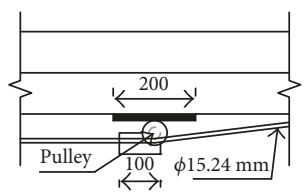

(d)

Figure 3: Strengthening technique details. (a) Longitudinal profile. (b) Detail D1 (anchor assembly). (c) View A-A. (d) Detail D2 (deviator).

2.2. Testing Setup, Instrumentation, and Procedure. The test was conducted using a closed loop rig $2600 \mathrm{~mm}$ overall height $\times 2200 \mathrm{~mm}$ total width which equipped by $2000 \mathrm{kN}$ capacity hydraulic actuator with stroke and load control capabilities (Figure 4). The hydraulic actuator has $600 \mathrm{~mm}$ total stroke length, $10 \mathrm{kN}$ division, and $0-15 \mathrm{kN} / \mathrm{min}$ loading rate. The actuator was fixed to closed loop rig at the midspan of the tested girder. Two elastomeric bearing pads, $200 \mathrm{~mm}$ wide $\times 300 \mathrm{~mm}$ long $\times 64 \mathrm{~mm}$ thick, were used beneath the ends of the girder that achieved a span of $15,600 \mathrm{~mm}$ for the tested specimen. The bearing pads provided the required area for transmitting the load and allowed angular movement of the girder ends and, hence, simulated the actual supporting case in service in structural bridge systems over piers or abutments. To provide pure bending moment zone of $3600 \mathrm{~mm}$ long, all girders were tested to failure under a static third-point loading (Figure 5).

To identify crack appearance and propagation, the frontal side of the girder was prepared and painted with white water-based emulsion. The strains in strands and concrete during testing were measured at midspan using electrical resistance uniaxial strain gauges, foil type, which are attached to the strands and top of concrete deck slab. Moreover, at midspan across the cross section height, demec points have been installed to measure the concrete strain at different fiber levels using mechanical dial gauge with $0.002 \mathrm{~mm}$ unit division.

Deflection was measured at midspan section and sections located $3900 \mathrm{~mm}$ from the center of the supporting

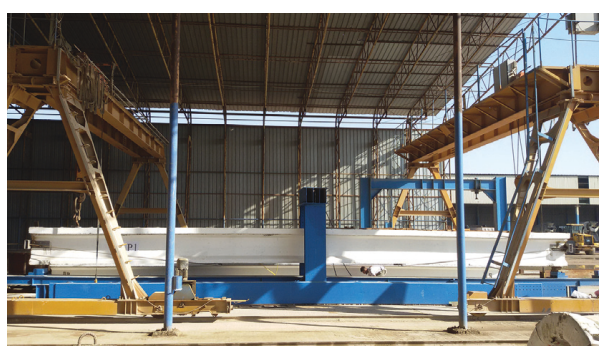

FIGURE 4: Testing rig.

elastomeric bearing pads, at quarter of the span at either side of the specimen, using three mechanical digital type transducers of $600 \mathrm{~mm}$ total linear displacement capacity. Also, two mechanical dial gauges, with $0.01 \mathrm{~mm}$ unit division, were used to fix the vertical displacement at supports. Wireless microscope with 200 times magnifying capacity was used for crack detecting and determining crack width. At the end of each test, the cracks propagation was marked, and the crack pattern and mode of failure for each specimen were carefully examined. Composite girders G1 and P1 were tested under static monotonic load with a loading rate of $5 \mathrm{kN} / \mathrm{min}$ and $10 \mathrm{kN}$ load increment, respectively, up to failure. Girders G2 and P2 were subjected to nonreversed repeated loading regime depending on the failure load of girders $\mathrm{G} 1$ and $\mathrm{P} 1$, respectively.

The repeated loading test sequence of the tested girders G2 and P2 was started by increasing the applied load up to 


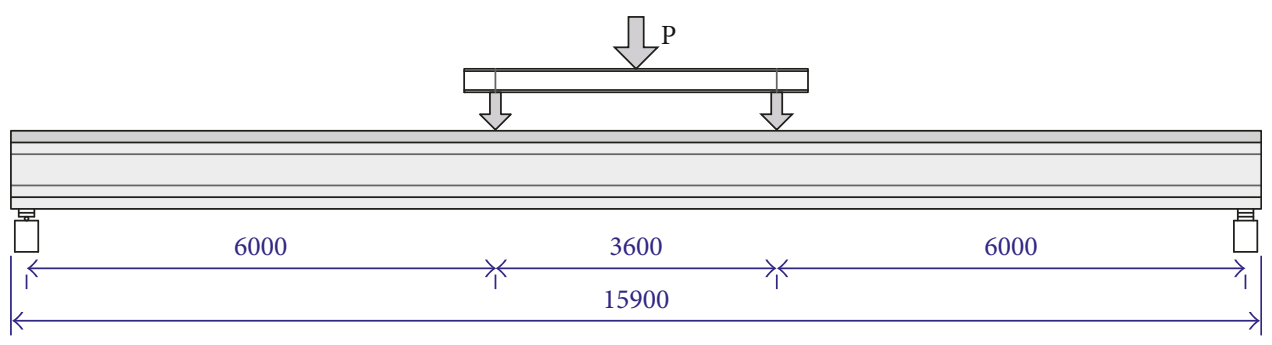

FIgURE 5: Load pattern for composite girders. Note: all dimensions are in $\mathrm{mm}$.

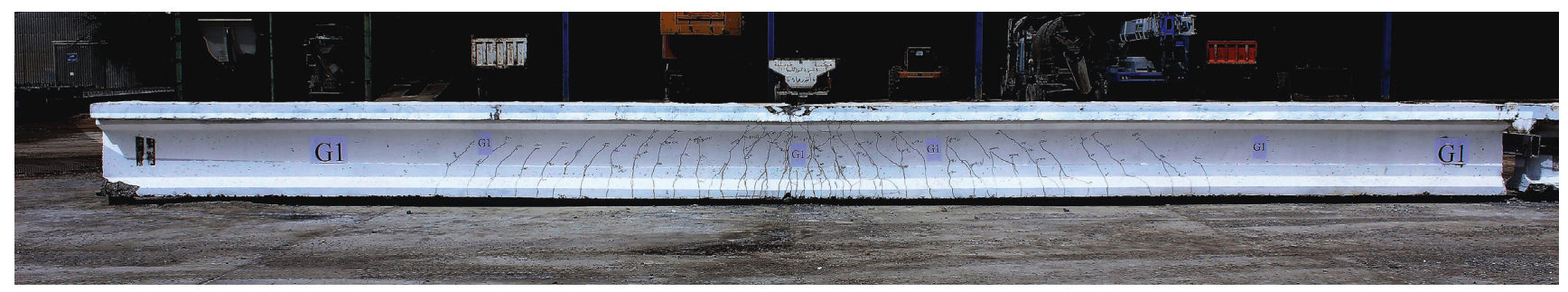

FIGURE 6: Crack pattern of girder G1 after testing.

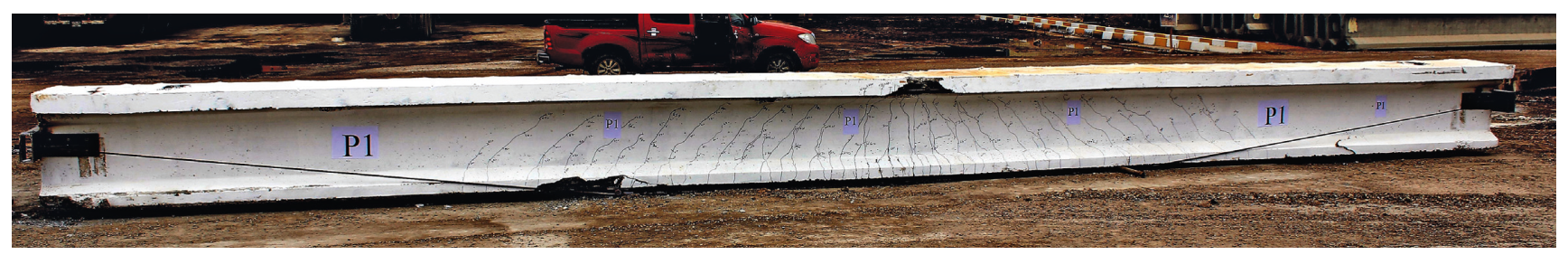

Figure 7: Crack pattern of girder P1 after testing.

a load level slightly higher than the cracking load of girders G1 and P1, respectively. The girders were then unloaded. Then, they have been reloaded gradually again at the rate of $5 \mathrm{kN} / \mathrm{min}$ and $10 \mathrm{kN}$ load increment up to (75\%) of the ultimate static failure load of the control girders G1 and P1, respectively, to study the behavior of those girders when they are subjected to a load level beyond the fatigue load, and then the load was gradually released to zero with 5 cycles of loading and unloading. After that, the two girders were reloaded gradually up to failure. In all specimens, the test was terminated when deflection increases dramatically under, approximately, constant load.

\subsection{Test Results for Girders Exposed to Monotonic Static} Loading. The typical crack patterns for girders G1 and P1 are illustrated in Figures 6 and 7. The first visible cracks generally appeared at midspan at total load level of $270 \mathrm{kN}$ and $333 \mathrm{kN}$, respectively. The appearance of the first crack for girder P1 was delayed due to the effect of external prestressing. Flexural cracks were gradually spreading horizontally from the midspan region toward the outer supports. Numbers of cracks started to increase with loading increment; wider cracks were developed after the initiating of the first crack. Main cracks for girder P1 were wide spreading out of the pure moment zone rather than the control girder G1.
As the load is increased, more visible cracks were observed with an increase in number and width and extended vertically toward the section compression zone. Figures 8 and 9 focus on the cracking propagation at the pure moment zone of composite girders $\mathrm{G} 1$ and $\mathrm{P} 1$, respectively. As indicated in Figure 10, the load-net deflection response for both girders exhibited three regions of behavior prior to rupture, which are precracking, postcracking, and postserviceability regions. In the precracking region, the loaddeflection curve was essentially a straight line defining full elastic behavior of the girders, and the girders were crack free. This region stopped at the initiation of the first flexural crack, when the concrete stress reached the value of modulus of rupture. In the postcracking region, girders G1 and P1 underwent varying degree of cracking along the span. Hence, cracks were wider and deeper at pure moment zones, whereas only narrow, minor cracks developed near supports. Accordingly, as the magnitude of cracking increased, girder stiffness continued to decrease resulting in less steep load-deflection curves.

In the postserviceability region, the substantial loss in stiffness due to the extensive cracking and considerable widening of cracks throughout the span led to that the load-deflection curves were considerably flatter than in the precracking regions. As the load continued to increase, the strain in strands and nonprestressed steel, at the tension zone of the section, continued to increase. After that, the rate 


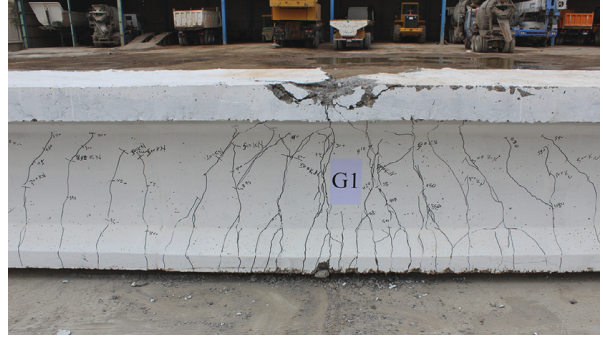

Figure 8: Concrete crushing at midspan of girder G1.

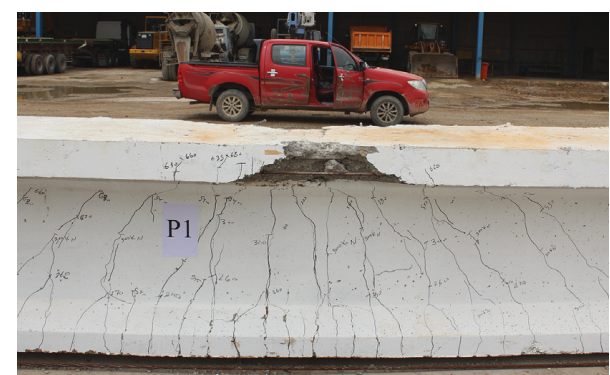

FIGURE 9: Concrete crushing at midspan of girder P1.

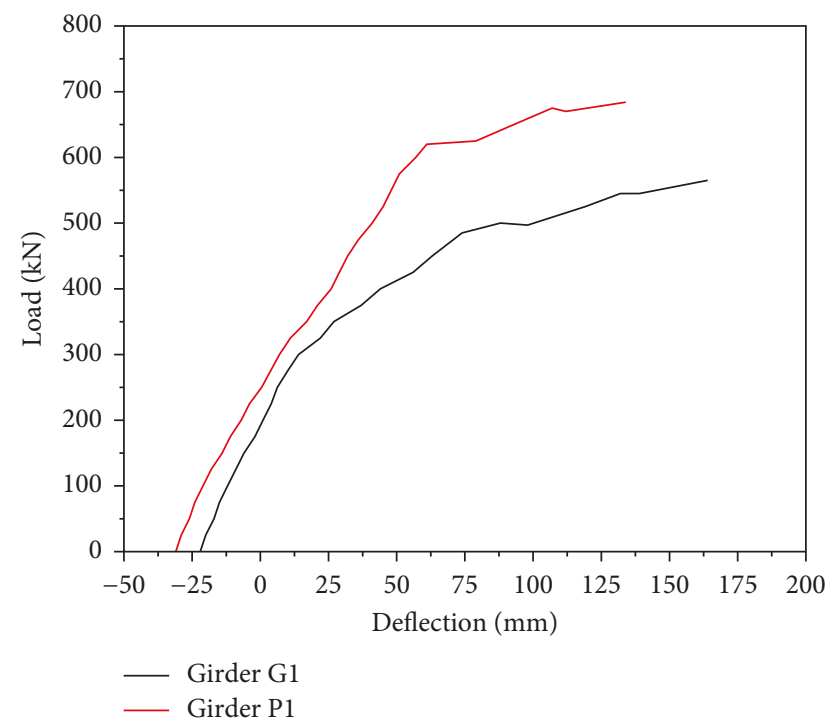

Figure 10: Load-net deflection curves at midspan for girders G1 and P1.

of deflection is rapidly increased and at load level of $550 \mathrm{kN}$ and $675 \mathrm{kN}$ for girders G1 and P1, respectively, a hearable rupture of internal strands happened where the pressure gauge readings is slightly dropped down. Girders G1 and P1 continued to deflect without considerable additional loading, and cracks continued to open. Finally, secondary compression failure developed, leading to total crushing of concrete of the deck slab and buckling of compression reinforcement bars in pure moment zone followed by failure at load levels of $565 \mathrm{kN}$ and $684 \mathrm{kN}$ for G1 and P1, respectively (Figures 8 and 9).

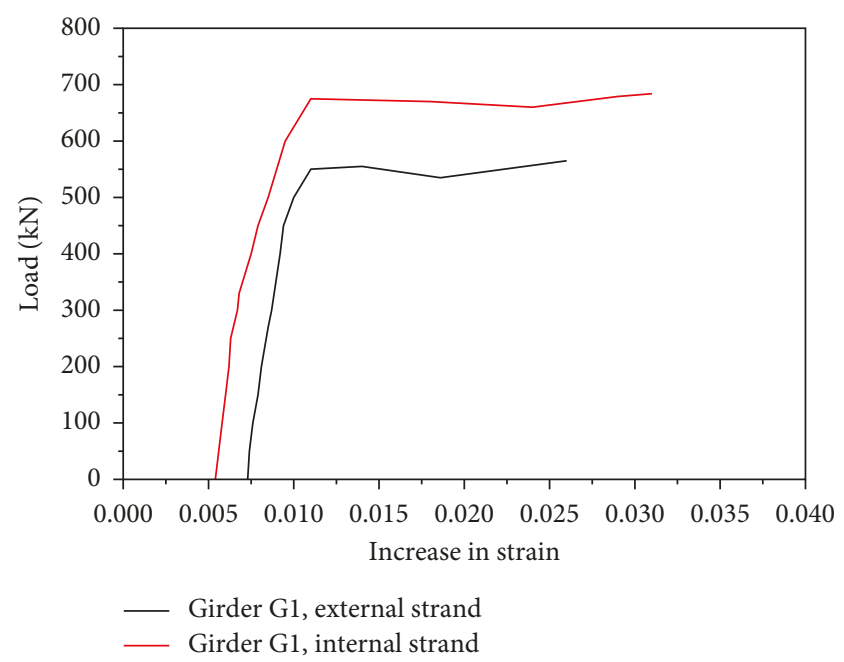

FIGURE 11: Increase of strain in prestressing strands of girders G1 and P1.

The maximum strain in internal strands of girder G1 was 0.026 . For girder $\mathrm{P} 1$, the maximum recorded strain values in the internal prestressing strands ranged between 0.009 and 0.01 , while for the external strand, the strain value ranged between 0.031 and 0.032 . Figure 11 shows the increase of strain in prestressing strands versus applied load. Before cracking, the strain in the internal tendons of unstrengthened girder G1 and the external strand of strengthened girder P1 is slightly increased with load increments. After cracking, the strain is substantially increased with increasing load level at the ultimate stage. Obviously, these girders exhibited semiductile flexural failure due to the presence of longitudinal nonprestressed reinforcement overall the section. So, the maximum deflection values were $186 \mathrm{~mm}$ and $164 \mathrm{~mm}$ for girders G1 and P1, respectively, while the maximum crack width was varied between $2 \mathrm{~mm}$ and $3 \mathrm{~mm}$. For girder P1, it was noted that concrete cover at left deviator was fragmented at failure load due to thrust force exerted from unbonded tendon. The residual net deflection after unloading was $92 \mathrm{~mm}$ and $78 \mathrm{~mm}$ for girders G1 and P1, respectively.

2.4. Comparisons of Test Results for Girders Exposed to Monotonic Static Loading. Cracking moment for girders G1 and P1 was calculated according to AASHTO LRFD [3] and ACI 318-14 provisions. Table 3 shows the values of the measured cracking moment and corresponding calculated values. Both AASHTO LRFD [3] and ACI 318-14 show conservative values of $M_{\mathrm{cr}}$ for both girders.

Experimental and theoretical moment-curvature diagrams for midspan section are illustrated in Figures 12 and 13 for girders G1 and P1, respectively. The values of curvature were calculated using strain compatibility analysis based on effective stress value in unbonded tendons given in both AASHTO LRFD (provisions (5.7.3.1.2)) [3] and ACI 318:2014 (provision (20.3.2.4.1)). Table 4 presents a comparison between these results. It should be mentioned that 
TABle 3: Cracking moment $M_{\mathrm{cr}}$ values for girders G1 and P1.

\begin{tabular}{lccc}
\hline Girder & $\begin{array}{c}M_{\mathrm{cr}}, \mathrm{kN} \cdot \mathrm{m} \\
\text { experimental }\end{array}$ & $\begin{array}{c}M_{\mathrm{cr}}, \mathrm{kN} \cdot \mathrm{m} \text { according } \\
\text { to AASHTO LRFD } \\
\text { and ACI }\end{array}$ & $\left(M_{\mathrm{cr}, \mathrm{cal} .} / M_{\mathrm{cr}, \text { exp. }}\right), \%$ \\
\hline G1 & 1085 & $998^{*}$ & 91.98 \\
P1 & 1275 & $1194^{*}$ & 93.65 \\
\hline
\end{tabular}

${ }^{*} M_{\text {cr }}$ is calculated using modulus of rupture $\left(f_{r}\right)$ at date of test and including dead load effect according to $M_{\mathrm{cr}}=S_{c}\left(f_{r}+f_{\text {cpe }}\right)$, where $S_{c}$ is the composite section modulus and $f_{\text {cpe }}$ is the compressive stress in the concrete due to effective prestressing force.

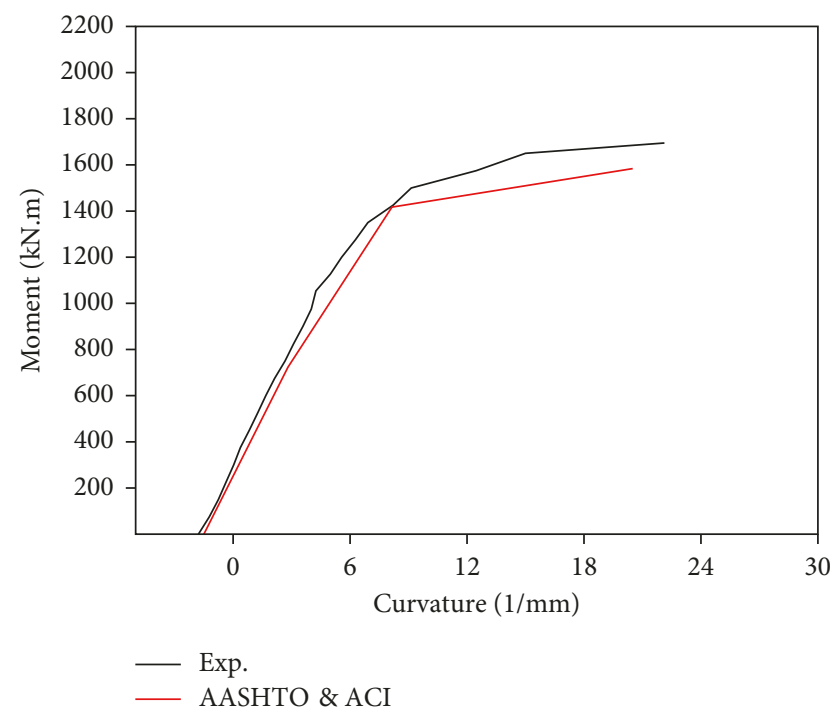

FIgURE 12: Moment-curvature for control girder G1.

the calculated values according to these codes were close to the experimental results.

Values of yielding and ultimate moments were obtained according to the strain compatibility analysis by adopting the measured strain value of 0.01 for the internal pretensioned tendons, and the measured strain for external unbonded posttensioned strand is 0.0032 according to the test results.

Both code provisions for yielding and ultimate moments are coinciding for girder G1. For girder P1, it is clearly seen that the ACI 318-14 (provision (20.3.2.4.1)) gives smaller value for the ultimate moment by $96.5 \%$ for the ultimate moment, while the AASHTO LRFD [3] (provisions (5.7.3.1.2)) is considered closer for both experimental results and compatibility strain analysis approach based on measured strain for the unbonded tendons. Hence, it can be concluded that AASHTO LRFD [3] provisions can be adopted for case of girders with internal pretensioned and external strengthened with unbonded tendons. The effect of adding external posttensioned strands for girder P1 is summarized in Table 5. Relation between moments, deflections, and the resulting curvatures, through loading, is necessary to assess member ductility.

Before loading, both girders had a curvature of negative sign due to camber deformation after jacking process. Ductility index (the ratio of deflection at ultimate load $\left(\Delta_{u}\right)$

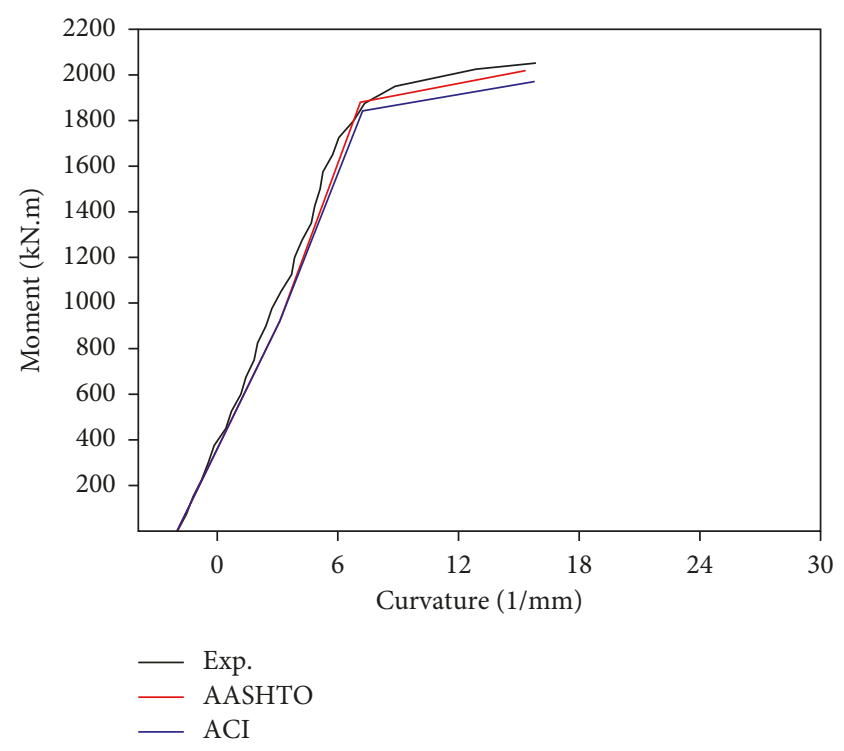

Figure 13: Moment-curvature for control girder P1.

to deflection at yield load $\left.\left(\Delta_{y}\right)\right)$ is calculated to show the effect of strengthening on the ability to carry inelastic deformation. Test results referred that a reduction in the ductility index was observed for girder P1. On the other hand, maximum deflection value for the strengthened girder P1 was reduced to $95.6 \%$ at yield and $88.7 \%$ at ultimate. At service load level (which is about $70 \%$ of ultimate load), the deflection was $36 \mathrm{~mm}$ for girder $\mathrm{G} 1$ and $32 \mathrm{~mm}$ for girder P1, which improves the serviceability limits. Also, there are enhancements in cracking moment, yield moment, and ultimate moment of $117.5 \%, 125.8 \%$, and $118.1 \%$, respectively. This increase in the moment capacity is due to the axial force exerted by the external unbonded tendons. It can be shown that the value of ductility index ratio was decreased by $92.4 \%$ when using externally unbonded tendons as the strengthening technique.

2.5. Test Results for Girders Exposed to Repeated Static Loading. The typical crack patterns for girders G2 and P2 are illustrated in Figures 14 and 15 . The first visible cracks generally appeared at midspan at load level of $274 \mathrm{kN}$ and $327 \mathrm{kN}$, respectively, which is considered similar to those obtained for girders G1 and P1. The repeated loading test sequence for the tested girders was started by increasing the applied load up to a load level slightly higher than the cracking load of girders G1 and P1 (i.e., $280 \mathrm{kN}$ and $340 \mathrm{kN}$, resp.), where these values are considered as $P_{\min }$. The girders were then unloaded which resulted in reducing the cambers of the girders by $3 \mathrm{~mm}$ due to residual deflections. Then, the girders were first reloaded gradually again at the rate of $5 \mathrm{kN} / \mathrm{min}$ and $10 \mathrm{kN}$ load increment up to $P_{\max }$ and then subjected to five statically applied load cycles between $P_{\min }$ and $P_{\max }$. While the level $P_{\max }$ in repeated load was selected in advance (about $75 \%$ of the total ultimate static failure load of the control girders G1 and P1, i.e., $425 \mathrm{kN}$ and $513 \mathrm{kN}$, resp.). This is to study the behavior of those girders when 
TABLE 4: Yielding and ultimate moment values for girders G1 and P1.

\begin{tabular}{|c|c|c|c|c|c|c|c|c|}
\hline \multirow{3}{*}{ Girder } & \multicolumn{2}{|c|}{ Experimental values } & \multicolumn{6}{|c|}{ Theoretical values } \\
\hline & & & \multicolumn{2}{|c|}{ ACI $318-14$ provisions } & \multicolumn{2}{|c|}{ AASHTO LRFD [3] provisions } & \multicolumn{2}{|c|}{ Strain compatibility analysis } \\
\hline & $\begin{array}{c}M_{y, \text { exp. }} \\
\mathrm{kN} \cdot \mathrm{m}\end{array}$ & $M_{u, \exp }{ }^{*}, \mathrm{kN} \cdot \mathrm{m}$ & $\begin{array}{c}M_{y, \text { cal. }}, \mathrm{kN} \cdot \mathrm{m} \\
\left(M_{y, \text { cal }} / M_{y, \text { exp }}\right)\end{array}$ & $\begin{array}{c}M_{u, \text { cal. }}, \mathrm{kN} \cdot \mathrm{m} \\
\left(M_{u, \text { cal. }} / M_{u, \text { exp. }}\right)\end{array}$ & $\begin{array}{c}M_{y, \text { cal. }}, \mathrm{kN} \cdot \mathrm{m} \\
\left(M_{y, \text { call }} / M_{y, \text { exp. }}\right)\end{array}$ & $\begin{array}{c}M_{u, \text { cal. }}, \mathrm{kN} \cdot \mathrm{m} \\
\left(M_{u, \text { cal. }} / M_{u, \text { exp. }}\right)\end{array}$ & $\begin{array}{c}M_{y, \text { cal }}, \mathrm{kN} \cdot \mathrm{m} \\
\left(M_{y, \text { cal. }} / M_{y, \text { exp. }}\right)\end{array}$ & $\begin{array}{c}M_{u, \text { cal. }}, \mathrm{kN} \cdot \mathrm{m} \\
\left(M_{u, \text { call }} / M_{u, \text { exp. }}\right)\end{array}$ \\
\hline G1 & 1696 & 1969 & $\begin{array}{c}1691 \\
99.7 \%\end{array}$ & $\begin{array}{c}1859 \\
94.4 \%\end{array}$ & $\begin{array}{c}1691 \\
99.7 \%\end{array}$ & $\begin{array}{c}1859 \\
94.7 \%\end{array}$ & $\begin{array}{c}1663 \\
98.0 \%\end{array}$ & $\begin{array}{c}1941 \\
98.6 \%\end{array}$ \\
\hline P1 & 2134 & 2326 & $\begin{array}{c}2112 \\
99.0 \%\end{array}$ & $\begin{array}{c}2245 \\
96.5 \%\end{array}$ & $\begin{array}{c}2154 \\
101.0 \%\end{array}$ & $\begin{array}{c}2293 \\
98.6 \%\end{array}$ & $\begin{array}{c}2102 \\
98.5 \%\end{array}$ & $\begin{array}{c}2313 \\
99.4 \%\end{array}$ \\
\hline
\end{tabular}

${ }^{*} M_{y}$ and $M_{u}$ are calculated considering the value of dead load moment.

TABLe 5: Summary of test results for girders G1 and P1.

\begin{tabular}{|c|c|c|c|}
\hline Test results & Girder G1 & Girder P1 & $(\mathrm{P} 1 / \mathrm{G} 1), \%$ \\
\hline Initial camber, $\mathrm{mm}$ & 22 & 31 & 140.9 \\
\hline Total $P_{\mathrm{cr}}, \mathrm{kN}$ & 361.6 & 425 & 117.5 \\
\hline$M_{\mathrm{cr}}, \mathrm{kN} \cdot \mathrm{m}$ & 1085 & 1275 & 117.5 \\
\hline$\Delta_{\mathrm{cr}}, \mathrm{mm}^{*}$ & 32 & 42 & 131.3 \\
\hline Total $P_{y}, \mathrm{kN}$ & 565.3 & 711.3 & 125.8 \\
\hline$M_{y}, \mathrm{kN} \cdot \mathrm{m}$ & 1696 & 2134 & 125.8 \\
\hline$\Delta_{y}, \mathrm{~mm}^{*}$ & 96 & 92 & 95.6 \\
\hline Curvature $\phi_{y}, 1 / \mathrm{mm} \times 10^{-5}$ & 7.92 & 7.36 & 95.8 \\
\hline Total $P_{u}, \mathrm{kN}$ & 656.3 & 775.3 & 118.1 \\
\hline$M_{u}, \mathrm{kN} \cdot \mathrm{m}$ & 1969 & 2326 & 118.1 \\
\hline$\Delta_{u}, \mathrm{~mm}^{*}$ & 186 & 165 & 88.7 \\
\hline Residual deflection, mm & 92 & 78 & 84.8 \\
\hline Curvature $\phi_{u}, 1 / \mathrm{mm} \times 10^{-5}$ & 22.13 & 15.85 & 71.6 \\
\hline Ductility index, $\Delta_{u} / \Delta_{y}$ & 1.94 & 1.79 & 92.4 \\
\hline$\Delta$ at service load level ( $70 \%$ of ultimate load), $\mathrm{mm}^{\#}$ & 36 & 32 & 88.9 \\
\hline
\end{tabular}

${ }^{*}$ Total absolute measured downward net deflection, ${ }^{*}$ net deflection after subtracting camber value.

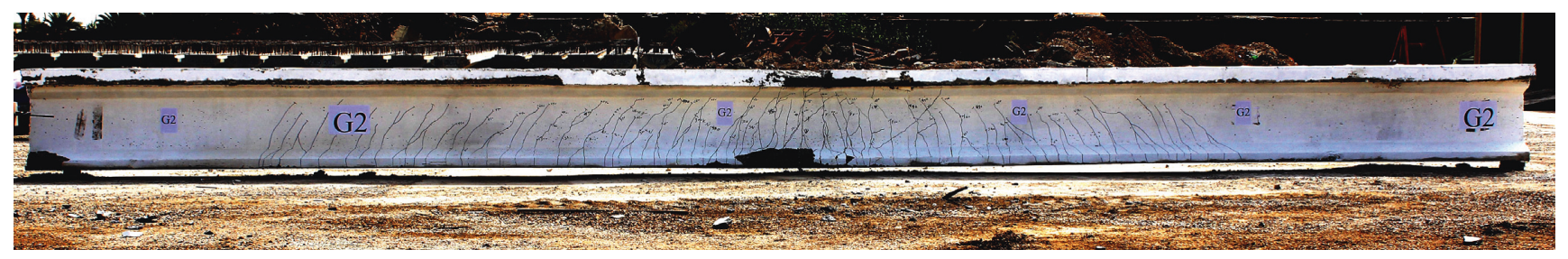

FIGURE 14: Crack pattern of girder G2 after testing.

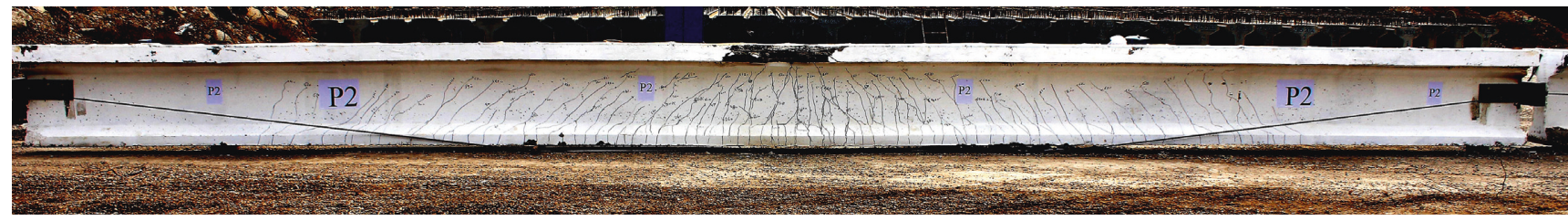

FiguRe 15: Crack pattern of girder P2 after testing.

they are subjected to a load level beyond the fatigue load, and then the load was gradually released to zero with 5 cycles of loading-unloading. After that, the two girders were reloaded gradually up to failure. When applying the first cycle of loading, more cracks appeared at the bottom flange of girders G2 and P2 when the load level reached to $425 \mathrm{kN}$ and $513 \mathrm{kN}$, respectively.

During the second cycle of loading, it was noted that the cracks reopened and propagated. The maximum measured crack width for both girders was $0.06 \mathrm{~mm}$ where all cracks 


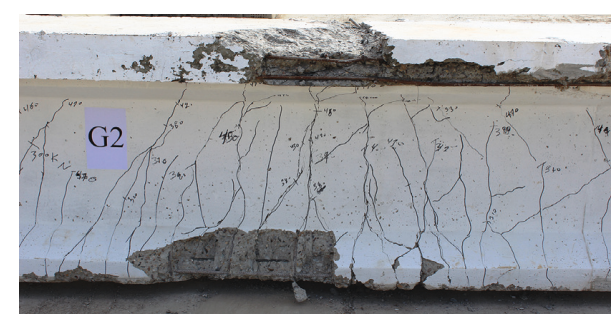

FIgURE 16: Concrete crushing at midspan of girder G2.

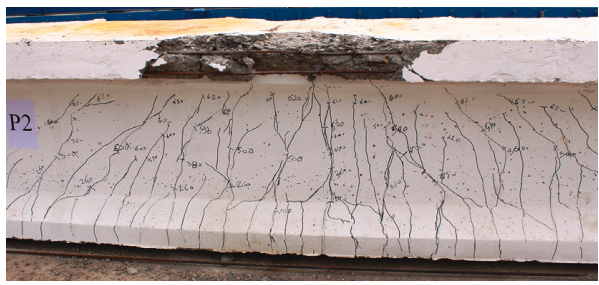

Figure 17: Concrete crushing at midspan of girder P2.

appeared within the middle third of the span. At the third and fourth cycles, cracks initiated as the previous two cycles began to increase in width which varied from $0.1 \mathrm{~mm}$ to $0.14 \mathrm{~mm}$. Spacing between cracks remained approximately constant but cracks were deeper extending toward the deck slab. At the fifth cycle, the maximum crack width varied from $0.4 \mathrm{~mm}$ to $0.6 \mathrm{~mm}$, average spacing between cracks was $110 \mathrm{~mm}$ at the bottom flange, and the maximum depth of cracks was $680 \mathrm{~mm}$. It should be noted that, at the end of the fifth loading cycle, cracks occupied the whole diapason of the span up to the zone of $0.9 \mathrm{~m}$ from each support. Also, as expected, during the repeated loading, the residual deflection was increased. After completing the repeated loading process, both girders were loaded up to failure. The numbers of cracks increased with loading increment, and wider cracks were developed. After that, the rate of deflection rapidly increased, and at load level of $455 \mathrm{kN}$ and $610 \mathrm{kN}$ for girders G2 and P2, respectively, a hearable rupture of internal strands was noted where the pressure gauge readings slightly dropped down. Girders G2 and P2 continued to deflect without considerable additional loading, and cracks continued to open.

Finally, secondary compression failure developed, where successive falling of concrete pieces which led to total crushing of concrete of the deck slab and buckling of compression reinforcement bars in pure moment zone was followed by failure at load levels of $520 \mathrm{kN}$ and $618 \mathrm{kN}$ for G2 and P2, respectively (Figures 16 and 17). The concrete of deck slab had a crushing area length of $1.1 \mathrm{~m}$ to $1.3 \mathrm{~m}$ long at midspan, and the longitudinal reinforcement bent out due to loss of the confinement of concrete cover. The residual net deflection after unloading was $88 \mathrm{~mm}$ and $76 \mathrm{~mm}$ for girders G2 and P2, respectively. Obviously, the crack patterns and mode of failure for the specimen exposed to repeated load were similar to that of girders tested under static load.

2.6. Comparisons of Test Results for Girders Exposed to Repeated Static Loading. The load-deflection response of the

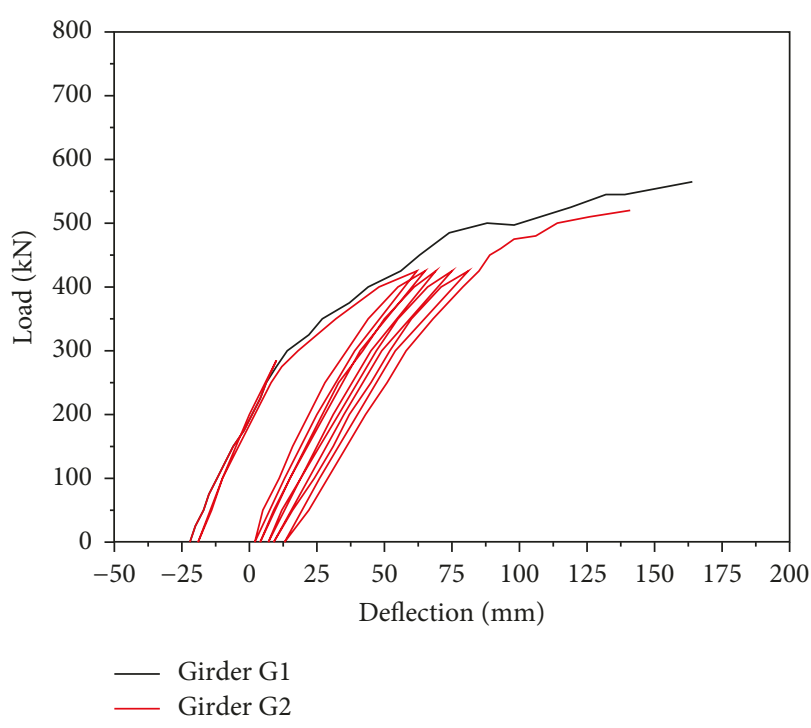

FIGURE 18: Load-net deflection curves for girder G2 under repeated loading.

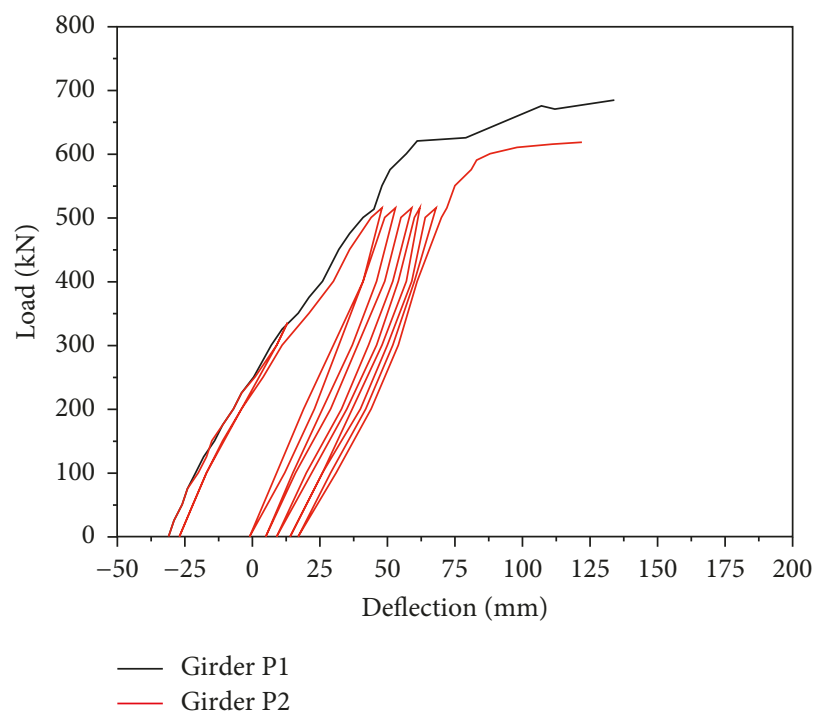

Figure 19: Load-net deflection curves for girder P2 under repeated loading.

specimens tested under repeated loading are shown in Figures 18 and 19. It is noticed that the load-deflection behavior is approximately identical for both girders. It should be observed that, at the same loading level; as the number of cycles was increased, the deflection of the member was increased accordingly. The residual net deflection after unloading was $119 \mathrm{~mm}$ and $91 \mathrm{~mm}$ for girders G2 and P2, respectively. The deflection values at yield and ultimate loads were compared with that for the reference girders as illustrated in Table 6. The additional measured strain for external unbonded posttensioned strand of girder $\mathrm{P} 2$ was 0.0026 . This reduction in strain value was due to the change in tendon eccentricity, that is, the second-order 
Table 6: Summary of test results for girders G2 and P2.

\begin{tabular}{|c|c|c|c|c|c|}
\hline Test results & Girder G2 & G2/G1, \% & Girder P2 & $\mathrm{P} 2 / \mathrm{P} 1, \%$ & $\mathrm{P} 2 / \mathrm{G} 2, \%$ \\
\hline$M_{\mathrm{cr}}, \mathrm{kN} \cdot \mathrm{m}$ & 1096 & 101 & 1255 & 98.4 & 114.5 \\
\hline$\Delta_{\mathrm{cr}}, \mathrm{mm}^{*}$ & 32 & 100 & 44 & 104.8 & 137.5 \\
\hline$M_{y}, \mathrm{kN} \cdot \mathrm{m}$ & 1639 & 96.6 & 2104 & 98.6 & 128.4 \\
\hline$\Delta_{y}, \mathrm{~mm}^{*}$ & 113 & 117.7 & 136 & 147.8 & 120.4 \\
\hline$M_{u}, \mathrm{kN} \cdot \mathrm{m}$ & 1834 & 93.1 & 2128 & 91.5 & 116.0 \\
\hline$\Delta_{u}, \mathrm{~mm}^{*}$ & 163 & 87.6 & 153 & 92.7 & 93.9 \\
\hline Residual deflection, mm & 119 & 129.3 & 91 & 116.7 & 76.6 \\
\hline Ductility index, $\Delta_{u} / \Delta_{y}$ & 1.44 & 74.2 & 1.13 & 63.1 & 78.5 \\
\hline$\Delta$ at service load level ( $70 \%$ of ultimate load), $\mathrm{mm}^{\#}$ & 65 & 180 & 61 & 191 & 93.8 \\
\hline
\end{tabular}

*Total absolute measured downward net deflection, ${ }^{*}$ net deflection after subtracting camber value.

TABLE 7: Comparison between FEM and experimental results.

\begin{tabular}{|c|c|c|c|c|c|c|c|}
\hline Girder & Value & $M_{\mathrm{cr}}, \mathrm{kN} \cdot \mathrm{m}$ & $\Delta_{\mathrm{cr}}, \mathrm{mm}$ & $M_{y}, \mathrm{kN} \cdot \mathrm{m}$ & $\Delta_{y}, \mathrm{~mm}$ & $M_{u}, \mathrm{kN} \cdot \mathrm{m}$ & $\Delta_{u}, \mathrm{~mm}$ \\
\hline G1 & $\begin{array}{c}\text { FEM } \\
\text { Exp. } \\
\text { (FEM/Exp.) }\end{array}$ & $\begin{array}{c}1138 \\
1085 \\
104.9 \%\end{array}$ & $\begin{array}{c}30 \\
32^{*} \\
93.8 \%\end{array}$ & $\begin{array}{c}1830 \\
1696 \\
107.9 \%\end{array}$ & $\begin{array}{c}89 \\
96^{*} \\
92.7 \%\end{array}$ & $\begin{array}{c}2096 \\
1969 \\
106.5 \%\end{array}$ & $\begin{array}{c}209 \\
186^{*} \\
112.4 \%\end{array}$ \\
\hline G2 & $\begin{array}{c}\text { FEM } \\
\text { Exp. } \\
\text { (FEM/Exp.) }\end{array}$ & $\begin{array}{l}1216 \\
1096 \\
111 \%\end{array}$ & $\begin{array}{c}31.4 \\
32^{*} \\
98.1 \%\end{array}$ & $\begin{array}{c}1708 \\
1639 \\
104.2 \%\end{array}$ & $\begin{array}{c}115 \\
113^{*} \\
101.8 \%\end{array}$ & $\begin{array}{c}1918 \\
1834 \\
104.6 \%\end{array}$ & $\begin{array}{c}175 \\
163^{*} \\
107.4 \%\end{array}$ \\
\hline P1 & $\begin{array}{c}\text { FEM } \\
\text { Exp. } \\
\text { (FEM/Exp.) }\end{array}$ & $\begin{array}{c}1348 \\
1275 \\
105.7 \%\end{array}$ & $\begin{array}{c}40 \\
42^{*} \\
95.3 \%\end{array}$ & $\begin{array}{c}2264 \\
2134 \\
106.1 \%\end{array}$ & $\begin{array}{c}89 \\
92^{*} \\
96.7 \%\end{array}$ & $\begin{array}{c}2417 \\
2326 \\
103.9 \%\end{array}$ & $\begin{array}{c}179 \\
165^{*} \\
108.5 \%\end{array}$ \\
\hline $\mathrm{P} 2$ & $\begin{array}{c}\text { FEM } \\
\text { Exp. } \\
\text { (FEM/Exp.) }\end{array}$ & $\begin{array}{c}1297 \\
1255 \\
103.3 \%\end{array}$ & $\begin{array}{c}43.5 \\
44^{*} \\
98.9 \%\end{array}$ & $\begin{array}{c}2137 \\
2104 \\
101.6 \%\end{array}$ & $\begin{array}{c}125 \\
129^{*} \\
96.9 \%\end{array}$ & $\begin{array}{c}2188 \\
2128 \\
102.8 \%\end{array}$ & $\begin{array}{c}163 \\
153^{*} \\
106.7 \%\end{array}$ \\
\hline
\end{tabular}

* Total absolute measured downward net deflection.

effects which led to a reduction in the ultimate moment capacity. Result of the tested girders G2 and P2 under repeated loading including the yield moment, the ultimate moment, and maximum deflection are illustrated in Table 7, which reveals clearly that there is an increase in yield and ultimate moments for the strengthened girders under repeated loading as compared with corresponding reference girders $\mathrm{G} 1$ and $\mathrm{P} 1$ by $128.4 \%$ and $116 \%$, respectively. Also, the suggested strengthening leads to an improvement in the serviceability limits regarding maximum and residual deflection under repeated loading.

\section{Finite Element Modeling (FEM)}

3.1. Material Properties and Modeling. A three-dimensional nonlinear finite element analysis has been used to conduct a numerical investigation on the general behavior of fullscale composite prestressed concrete girders strengthened with external posttensioning technique under static and repeated loading up to failure. ANSYS Program-Release 14.5 [16] software was utilized in this work. For modeling, concrete three-dimensional 8-node solid elements (SOLID 65 ) have been used. The element has eight corner nodes, and each node has three degrees of displacement in $x, y$, and $z$. The cracking of concrete is modeled as "smeared-cracking model." A crack is represented by an infinite number of parallel fissures across that part of the finite element. The element is capable of cracking (in three orthogonal directions), crushing, and plastic deformation. Modeling of reinforcing steel in connection with the finite element analysis of reinforced concrete members is much simpler than the modeling of concrete. The steel bars are long and relatively slender, and therefore, they can be assumed to transmit axial forces only. Accordingly, the embedded reinforcement model with an elastic-linear work hardening model is adopted to simulate the uniaxial stress-strain behavior of reinforcing steel bars. The steel reinforcement and prestressing strands were represented by using "bar elements" (discrete representation) with one degree of freedom at each node. The axial normal stress is assumed to be uniform over the entire element length. Perfect bond between steel reinforcement and concrete and between concrete and embedded tendons are assumed to occur [17]. Element SOLID 45 was used to model the steel plates, stiffeners, and deviators. This element consists of eight nodes with three degrees of freedom for each node, translations in the nodal $x, y$, and $z$ directions.

The four prestressed composite concrete girders have been analyzed to predict the ultimate flexural response. The girders were loaded in such manner like the experimental specimens with two-point loading. Due to symmetry, one half of each girder was used in the analysis and the required 


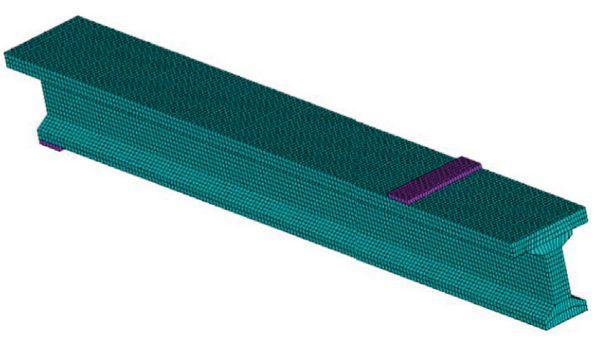

(a)

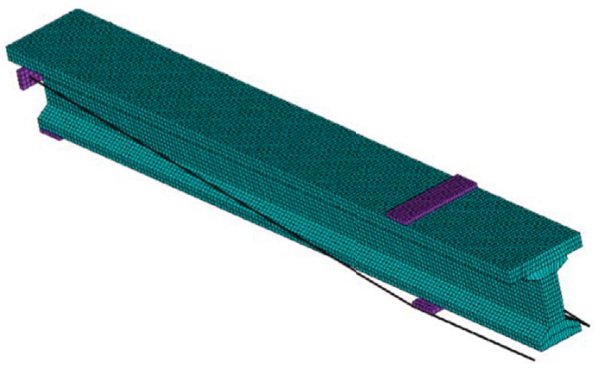

(b)

FIGURE 20: Finite element mesh and loading arrangement. (a) Girders G1 and P1. (b) Girders G2 and P2.

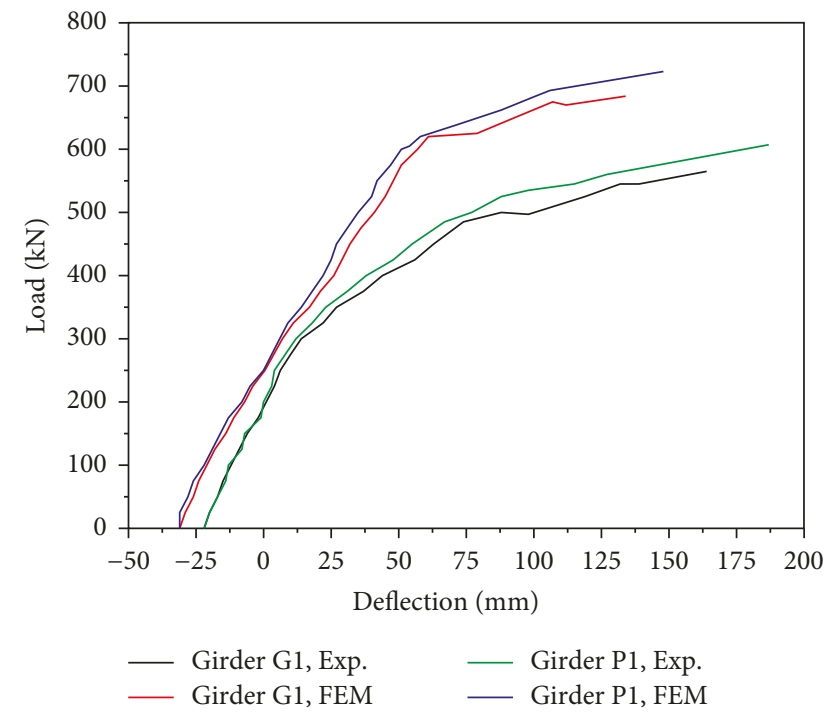

FIGURE 21: Comparison of FEM and experimental load-net deflection curves for girders G1 and P1.

displacement boundary conditions need to be applied at the support and symmetry line. The finite element mesh and the loading arrangement are shown in Figure 20. No external point load was applied in the first load step, the initial prestrain due to prestressing was applied to the girders, and the initial strains for real constant for prestressing strands were determined from effective prestress $\left(f_{\text {pe }}\right)$ and the modulus of elasticity $\left(E_{\mathrm{ps}}\right)$. Camber was observed in each beam. In the next step, the concentrated load was applied at the top of girders. Uniform increments of load have been used for applying the external load. The nonlinear analysis is conducted using the full Newton-Raphson method. A convergence tolerance of $5 \%$ is used. Different values for

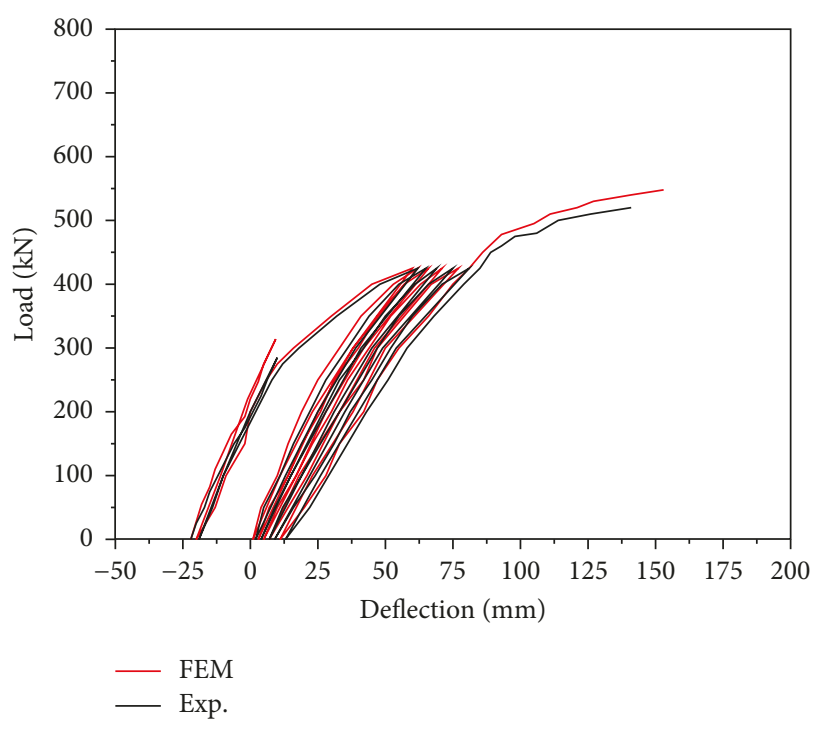

Figure 22: Comparison of FEM and experimental load-net deflection curves for girder G2.

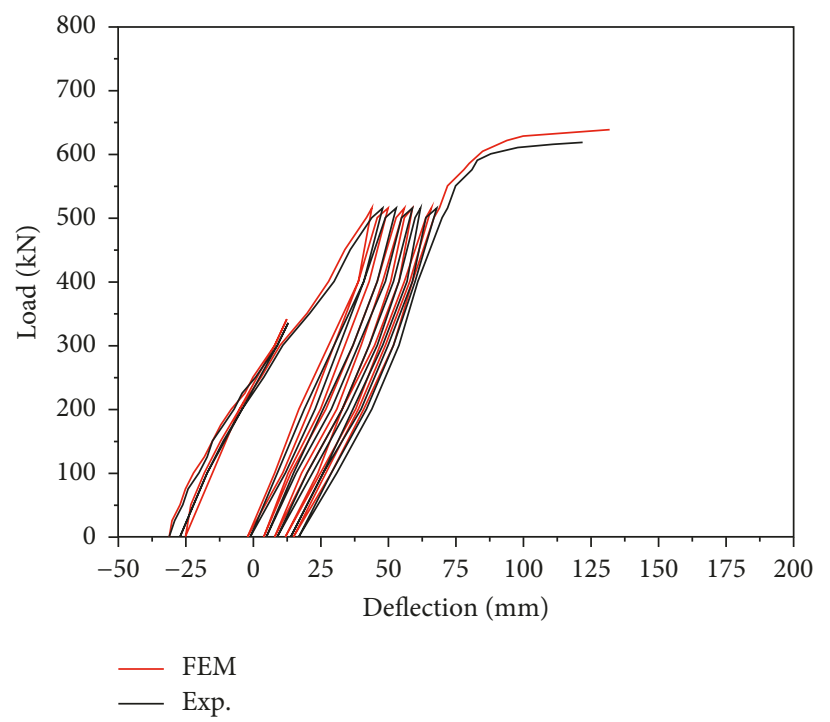

FIGURE 23: Comparison of FEM and experimental load-deflection curves for girder P2.

shear transfer parameters are used for each girder to obtain acceptable results. Nonlinear geometry analysis is also incorporated to include the second-order effect of the external unbonded tendons due to large deflection at stages close to failure load.

3.2. Comparisons of Experimental and FEM Results. The load versus net midspan deflection curves of the composite prestressed concrete girders obtained from the finite element analysis was compared with corresponding experimental data as shown in Figures 21-23 and Table 7 for all girders. In general, it can be noted that the finite element analyses agreed well with the experimental results throughout the 
entire range of behavior. The analysis results ranged between $2.8 \%$ and $6.5 \%$ for the ultimate moment capacities and between $6.7 \%$ and $12.4 \%$ for the maximum deflections. These values of discrepancy could be considered within acceptable range.

\section{Conclusions}

Four $15.9 \mathrm{~m}$ length composite prestressed concrete girders have been tested under static and nonreverse repeated loading. Two girders were unstrengthened and tested as control girders, and other two girders were strengthened with external prestressing technique. Based on test results and FEM analysis, the following conclusions can be drawn:

(i) Strengthening with external prestressing technique exhibited a reasonable increase in the load carrying capacity. For the tested girders, the increase in cracking, yield, and ultimate moments attained $117.5 \%, 125.8 \%$, and $118.1 \%$, respectively.

(ii) Prestressed concrete girders strengthened with posttensioned unbonded tendons led to reduction in the ductility index and an improvement in the serviceability limits regarding deflection control at service load level.

(iii) The AASHTO LRFD provisions for predicting the ultimate tendon stress $f_{\mathrm{ps}}$ can be adopted for the case of pretension prestressed girders externally strengthened with unbonded tendons.

(iv) The strengthening with external posttensioned tendons led to increase in the yield and ultimate moments under repeated loading as compared with reference girders by $128.4 \%$ and 116 for the studied cases, respectively. Also, an improvement in the serviceability limits regarding maximum and residual deflection was achieved.

(v) The predicted numerical results by FEM using ANSYS software were in good agreement with the experimental results regarding ultimate loads, load-deflection response, and crack patterns for both static and repeated loading. The analysis results in a difference ranged between $2.8 \%$ and $6.5 \%$ for the ultimate moments and between $6.7 \%$ and $12.4 \%$ for the maximum deflections. These ranges are considered within acceptable agreement as compared with experimental results.

\section{Conflicts of Interest}

The author declares that there are no conflicts of interest.

\section{Acknowledgments}

This project is supported by Hamorabi Company for Contracts (HCC), Ministry of Housing and Construction, Iraq, in testing and supplying raw materials needed to achieve this work. The author gratefully acknowledges the support received from the HCC.

\section{References}

[1] A. F. Nasir and W. Zonglin, "Strengthening of Jiamusi prestressed highway bridge by using external post-tensioning technology in China," ARPN Journal of Engineering and Applied Sciences, vol. 5, no. 11, pp. 60-69, 2010.

[2] A. E. Naaman and F. M. Alkhairi, "Stress at ultimate in unbonded post-tensioned tendons: Part 2-proposed methodology," ACI Structural Journal, vol. 88, no. 6, pp. 683-692, 1991.

[3] AASHTO LRFD, AASHTO LRFD Bridge Design Specifications, U.S. Customary Units with 2015 and Interim Revisions, American Association of State Highway and Transportation Officials, Washington, DC, USA, 7th edition, 2016.

[4] Building Code Requirements for Structural Concrete, (ACI 318-14), and Commentary (ACI 318R-14), American Concrete Institute, Farmington Hills, MI, USA, 2014.

[5] M. Harajli, N. Khairallah, and H. Nassif, "Externally prestressed members evaluation of second order effects," Journal of Structural Engineering, vol. 125, no. 10, pp. 1151-1161, 1999.

[6] M. H. Harajli, M. E. Mabsout, and J. A. Al-Haji, "Response of externally post-tensioned continuous members," ACI Structural Journal, vol. 99, no. 5, pp. 671-680, 2002.

[7] K. Tan and R. A. Tjandra, "Shear deficiency in reinforced concrete continuous beams strengthened with external tendons," ACI Structural Journal, vol. 100, no. 5, pp. 565-572, 2003.

[8] C. K. Ng and K. H. Tan, "Flexural behavior of externally prestressed beams. Part II: experimental investigation," Engineering Structures Journals, vol. 28, no. 4, pp. 622-633, 2006.

[9] C. Sivaleepunth, J. Niwa, S. Tamura, and Y. Hamada, "Flexural behavior of externally prestressed concrete beams by considering loading application," Technical Paper, vol. 27, no. 2, pp. 553-558, 2005.

[10] S. H. Lee, H. D. Lee, K. J. Shin, and T. H. K. Kang, "Shear strength of continuous concrete beams using externally prestressed steel bars," PCI Journal, vol. 59, no. 4, pp. 77-92, 2014.

[11] A. Elrifai, J. West, and K. Soudki, "Fatigue of reinforced concrete beams strengthened with externally post-tensioned CFRP tendons," Construction and Building Materials, vol. 29, pp. 246-256, 2012.

[12] S. Ghasemi, A. A. Maghsoudi, H. A. Bengar, and H. R. Ronagh, "Flexural strengthening of continuous unbonded posttensioned concrete beams with end-anchored CFRP laminates," Structural Engineering and Mechanics, vol. 53, no. 6, pp. 1083-1104, 2015.

[13] K. H. E. Chan and F. T. K. Au, "Behavior of continuous prestressed concrete beams with external tendons," Structural Engineering and Mechanics, vol. 55, no. 6, pp. 1099-1120, 2015.

[14] A. El-Zohairy and H. Salim, "Parametric study for posttensioned composite beams with external tendons," Advances in Structural Engineering, vol. 20, no. 10, pp. 1433-1450, 2017.

[15] ASTM, Standard Specification for Low Relaxation, Seven-Wire Steel Strand for Prestressed Concrete, ASTM A416/A416M-17, vol. A01.05, American Society for Testing and Materials, West Conshohocken, PA, USA, 2017.

[16] ANSYS, ANSYS Element Manual, Release 14.5, Swanson Analysis System, Canonsburg, PA, USA, 2013.

[17] U. Kim, Y. Huang, P. Chakrabarti, and T. H. K. Kang, "Modeling of post-tensioned one-way and two-way slabs with unbonded tendons," Computer and Concrete, vol. 13, no. 5, pp. 547-561, 2014. 


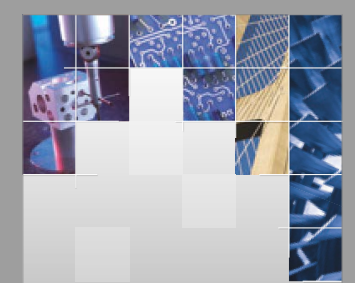

\section{Enfincering}
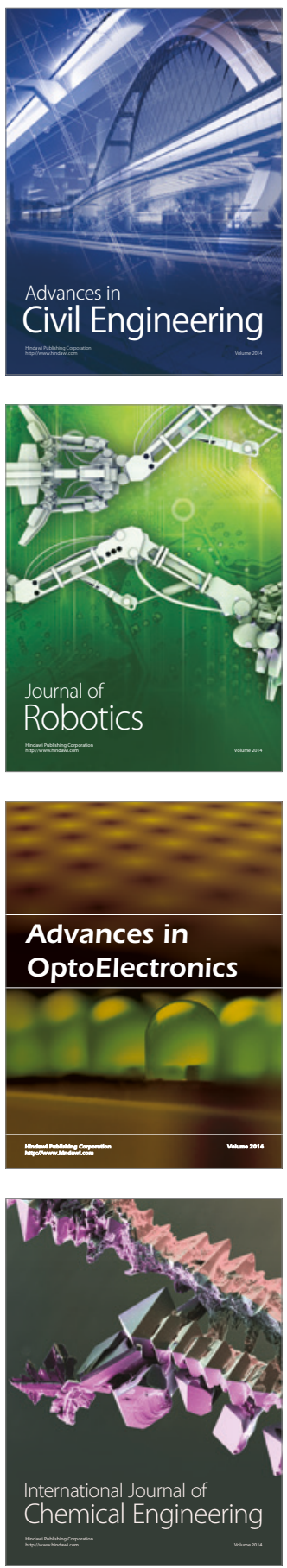

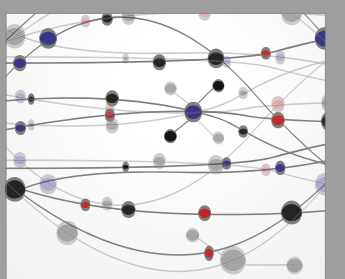

The Scientific World Journal

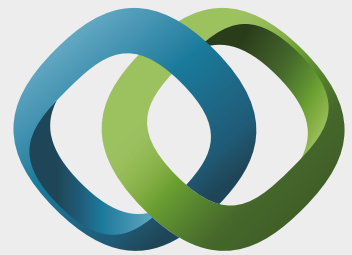

\section{Hindawi}

Submit your manuscripts at

https://www.hindawi.com
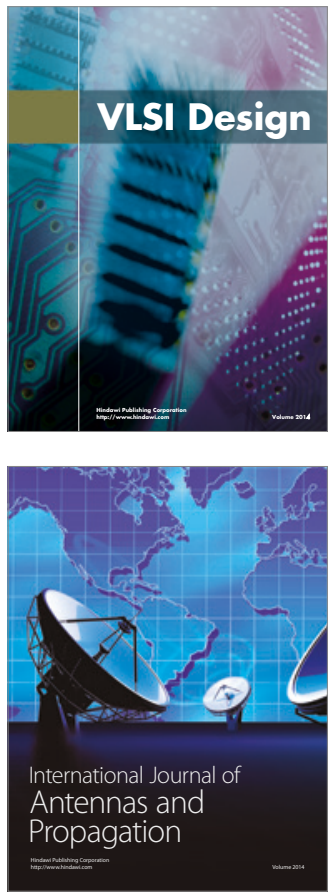

\section{Rotating}

Machinery
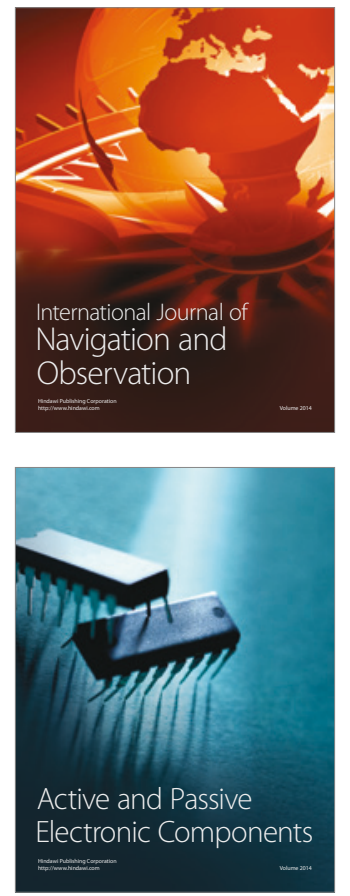
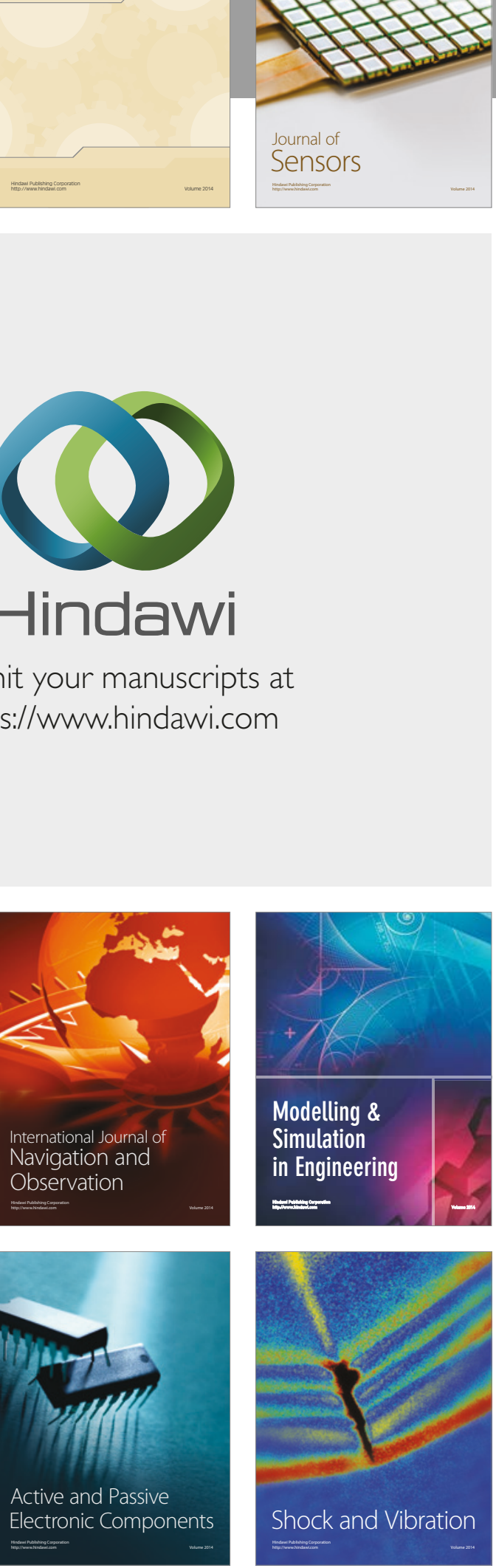
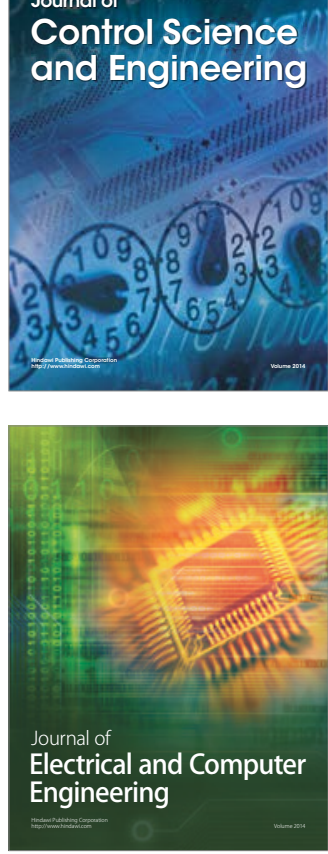

Distributed

Journal of

Control Science

and Engineering
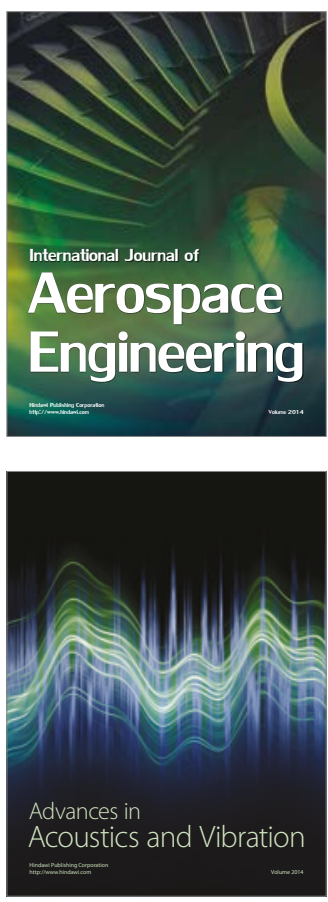

Sensor Networks 